\title{
Concept of Asnaf Al-Gharimin: Practices at Lembaga Zakat Selangor
}

\author{
Nurul'Ain Mohd 1, Mastura Razali 2, Aina Nabila Asmuri ${ }^{3}$, Muhamad Hasif Yahaya ${ }^{4}$ \\ ${ }^{1}$ Academy of Contemporary Islamic Studies, Universiti Teknologi Mara, Shah Alam, 40450, Selangor \\ ${ }^{2}$ Academy of Contemporary Islamic Studies, \\ Universiti Teknologi Mara, Cawangan Pulau Pinang, Kampus Permatang Pauh,13500, Pulau Pinang \\ ${ }^{3}$ Academy of Contemporary Islamic Studies, Universiti Teknologi Mara, Cawangan Selangor, Kampus Puncak Alam, 42300, Selangor
}

ainmohd@uitm.edu.my , mastura458@uitm.edu.my, ainanabila99@yahoo.com, hasifyahaya@uitm.edu.my Tel: +60132467418

\begin{abstract}
Each state in Malaysia interprets asnaf al gharimin differently due to the different ijtihad from the mufti. This study aims to analyze the practices of asnaf al gharimin based on Lembaga Zakat Selangor (LZS). Qualitative method based on interview is used in this article and supported by library research. The findings show that LZS has focused on four categories of debt to be given zakat assistance according to asnaf gharimin, including medical/ dialysis treatment assistance, life necessities assistance, management of the corpse without the heir, and debt association due to public concern.
\end{abstract}

Keywords: asnaf al- gharimin, debt; gharimin; zakat

eISSN: 2398-4287 @ 2021. The Authors. Published for AMER ABRA cE-Bs by e-International Publishing House, Ltd., UK. This is an open access article under the CC BYNCND license (http://creativecommons.org/licenses/by-nc-nd/4.0/). Peer-review under responsibility of AMER (Association of Malaysian Environment-Behaviour Researchers) , ABRA (Association of Behavioural Researchers on Asians) and cE-Bs (Centre for Environment-Behaviour Studies), Faculty of Architecture, Planning \& Surveying, Universiti Teknologi MARA, Malaysia.

DOI: https://doi.org/10.21834/ebpj.v6iSl6.3038

\subsection{Introduction}

Zakat is one of the five pillars in Islam and it requires all Muslims who are qualified to pay it. According to Mohamad Uda Kassim (2004), the meaning of zakat in terminology is accumulated in the Surah at-Taubah verse 103:

"Take, [O, Muhammad], from their wealth a charity by which you purify them and cause them increase and invoke [ Allah's blessings] upon them. Indeed, your invocations are reassurance for them. And Allah is Hearing and Knowing."

According to the verse, zakat will purify the one who put out the wealth and get the reward. Then, in Islamic terms, the meaning of zakat is a certain amount of property required by Allah SWT to be given to the rightful people, and the wealth that performs to zakat will become increasingly and more valuable and can protect the wealth from destruction. Ibnu Taimiyah gives the opinion that the soul of the person who performs zakat will be clean, and the wealth will be clean and increased. The way to purify wealth is based on theory, zakat is paid by the rich and will be distributed to the poor, and the zakat distribution process is expected to reach the optimum level of zakat. Therefore, this optimization process will have a great impact on the zakat in particular and on a country's economy in general. This is because the impact of this zakat distribution will not only be successful out of those who receive the zakat but will also contribute to the country's zakat. Finally, the asnaf has become part of the productive economy and contributes to the country's economy (Wahid, Ahmad, \& Abdul Kader, 2009).

Zakat is vital to the Muslim economy, especially in alleviating poverty. This is because poverty is one of the three devastating chains of ignorance, poverty and disease. Zakat is one of the funding sources for poverty alleviation by allocating most of the funds raised to the

eISSN: 2398-4287 @ 2021. The Authors. Published for AMER ABRA cE-Bs by e-International Publishing House, Ltd., UK. This is an open access article under the CC BYNCND license (http://creativecommons.org/licenses/by-nc-nd/4.0/). Peer-review under responsibility of AMER (Association of Malaysian Environment-Behaviour Researchers), ABRA (Association of Behavioural Researchers on Asians) and cE-Bs (Centre for Environment-Behaviour Studies), Faculty of Architecture, Planning \& Surveying, Universiti Teknologi MARA, Malaysia.

DOI: https://doi.org/10.21834/ebpj.v6iSI6.3038 
needy. The subsidy is given low proportion according to economic circumstances, time, place, and spending to meet their food needs, clothing, shelter, education, and health. Nevertheless, the aid and donated capital are not intended to encourage laziness, unemployment until threatening the peace and security of the country; instead, can ease the burden and being a source and encouragement of working for the needy and poor. The role of charity is important to close the gap between members of a community and redistribution of income according to the rights assigned (Omar, Kamaruddin \& Sungip, 2016)

Asnaf is a group that Allah has determined to receive alms aid. There are eight groups of people who have been described in surah al-Taubah verse 60 , which mean:

"Alms are for the poor and the needy, and those employed to administer the (funds); for those whose hearts have been (recently) reconciled (to Truth); for those in bondage and debt; in the cause of Allah. and for the wayfarer: (thus is it) ordained by Allah, and Allah is full of knowledge and wisdom."

This study aims to analyze the practices of asnaf al gharimin based on LZS. The scope of this study focuses on the type of zakat aid given to the asnaf al gharimin.

\subsection{Concept of Asnaf al Gharimin}

According to Hanafi school, al gharimin includes all who do not own nisab above what is needed to pay their debts. However, Maliki and Shafi'e and Ahmad distinguish between two kinds of debtors, those whose debts are for personal use and those whose debts are caused by their social and political responsibilities (al-Qaradawi 2011). Based on Sayed Sabiq (1983), al-Gharimin, eligible for zakat assistance, face financial problems due to money or property spent for the masses of people or suffered the loss in business or in managing a factory where all its losses are solely for the benefit of the public. In other words, those who are facing a debt burden for the common maslahah will only be given zakat money through the al-gharimin category. Based on these distinctions, Mujaini (2005) summarize al-gharimin to the following context:

* Indebtedness due to the self-necessity - the necessities are food, clothing, medical, transportation, wedding expenses such as marriage, house building and accidental damage to personal belongings.

- Indebtedness to the public interest of Muslims (maslahah); a situation in which the people are beholden to the public interest and the welfare of Muslims. For example, they are harmonizing or blocking hostility between two groups, leading to bloodshed and property damage. In addition, this group includes a person indebted to replace the other party's property, which suffers losses so that both parties are not fighting. In addition, in the context of welfare and public interest are the construction of places of worship, research centres, the provision of hospital facilities, the establishment of a Foundation of the elderly, orphans and orphans.

Table 1.1: Distribution of Zakat aid to asnaf al gharimin

\begin{tabular}{lcc}
\hline Types of zakat aid to asnaf al gharimin & \multicolumn{2}{c}{ Amount distribution (RM million) } \\
\cline { 2 - 3 } & $\mathbf{2 0 1 9}$ & $\mathbf{2 0 2 0}$ \\
\hline Medical debt assistance & 25.3 & 24.3 \\
Dialysis treatment debt assistance & 30.2 & 28.1 \\
Life necessities debt assistance & 6.9 & 6.2 \\
\hline \multicolumn{2}{c}{ Source: LZS (2020) Summary of zakat distribution and zakat collection LZS for the year ended 31st December 2020 }
\end{tabular}

Yusuf al-Qaradawi in the figh of zakat states that in matters of worship, it is not possible and impossible to perform ijtihad. This is because the illah of worship is most obscure. In addition, the law of worship needs to be obeyed ta'abbudi. However, zakat is different, and it is not a ta'abbudi (worship), but it includes the country's social, financial, and economic responsibilities. Zakat is also a form of worship that brings a clear maslahah to human life (Isamail, Rosele, Mohamad, \& Sulaiman@Mohamad, 2015). Therefore, in resolving zakat or establishing a zakat law, it is necessary to celebrate the maslahah (Rosele, M. I., Md Ariffin, M. F., Ramli, M. A., \& Isamai, M. Z. ,2016). Different states in Malaysia provide a different interpretation of asnaf al-gharimin due to the different enactments of the Islamic religion. Tahir \& Yusof (2014) concludes that through the whole definition of State Zakat Institutions, asnaf al-gharimin is facing the problem of debt default. However, not all debtors are automatically included in the definition of gharimin eligible for zakat. It must be for Islamic law, that is, to meet the basic needs of itself, its family and its dependents. Differences interpretation by zakat institutions against the definition of asnaf gharimin outlined by the Syafie School is in the phrase indebted to the requirements of Syariah. The phrase carries a broad meaning and encompasses everything that permissible (mubah) be in Islam. However, to avoid misappropriation of the zakat fund, the specifics of what Shariah requires should be thoroughly researched. The difference in the meaning of the indebtedness in line with the 
requirements of the Shariah makes the difference in the assignment of qualifications al gharimin set by zakat institution (Mohammad, Engku Muhammad Tajuddin Engku Ali, \& Harun, 2014).

In Selangor, zakat aid to asnaf al gharimin has been distribute to the muslim in Selangor who is eligible to receive the aid. The following table show the amount of distribution towards the asnaf throughout the year of 2019 and 2020.

\subsection{Literature Review}

Few articles have discussed the definition of asnaf al gharimin. Ishak, M. F., Mahmoud, A. M. A., Salleh, H. M., Jamaludin, M. N. H., \& Karim, A. H. A. (2021) has discussed the concept of asnaf al gharimin from the point of view of the hadith of the Prophet. It explains that there are five characteristics of asnaf al-gharimin which can be determined based on the needs of society as well as existence various calamities, namely indebtedness as a result of meeting basic needs, indebtedness for the benefit of the ummah, guarantor to the debts of others, being saved by disasters and experiencing the deterioration of life due to epidemics. Mujaini (2005), Hasan Bahrom (2011), Azman Ab Rahman, Hasanah Abd Khafidz (2015) and Daud \& Ismail (2017) have study on zakat distribution to asnaf al-ghārimīn from the view of four primary schools of thought, contemporary scholars, and current practices according to the State Zakat Regulations in Malaysia. Mohammad et al., (2014) mentioned that the zakat institutions in Malaysia are in line with the Shafie School in the definition of asnaf. In general, the definition of gharimin asnaf for each zakat institution is the same but differences are seen in terms of gharimin asnaf qualification.

Several pieces of literature discuss the practices of asnaf al-gharimin to the current context. Mohammad, Khairuldin, Ali, Ismail, \& Rahman (2014) discuss qard hassan, which is linked to asnaf al gharimin. Qard Hasan's facilities from zakat institutions can help improve their economic status and provide an alternative to unlawful lending, thus avoiding corruption. They also believe that detailed studies need to be done on the market and implementation mechanisms to enable qard hasan units to be implemented within the zakat board. While Wahid, Ramli, Razak, and Zulkepli (2017) proposed categorizing flood victims as asnaf al gharimin in their research on the determination of zakat receivers to flood victims. They have divided the flood types according to minor, moderate, and major floods. In this case, the distribution for zakat recipients also varies in terms of one-off zakat distribution for only moderate victims; however, major flood victims will be given under al- gharimin recipients due to the loss of their livelihoods and homes destroyed. Giving zakat based on the level of flooding guarantees the lives of flood victims after suffering damage from the flood disaster. In their research, Tahir \& Yusof (2014) analyze the eligibility bankruptcy person to be categorized as asnaf al-gharimin. The analysis shows that the debt purpose for the bankrupt individuals is to be seen as most important in determining their eligibility for zakat to pay off their debts. The purpose of non-shariah compliant debt, such as spending lavishly on luxury, is not in line with al-gharimin's definition. In Selangor The practice in the state of Selangor is found to be more detailed in the context of the distribution of zakat to al-gharimin by imposing certain conditions on the debt. This shows that not all indebted people are eligible to receive zakat distribution under asnaf al-gharimin, but instead those who are actually in debt for basic and desperate needs are eligible to receive zakat (Ibrahim, M. F., \& Sahrim, M,. 2019)

The corporation process of zakat management in the state of Selangor can be illustrated with the figure below:

Figure 2.0: History timeline of LZS

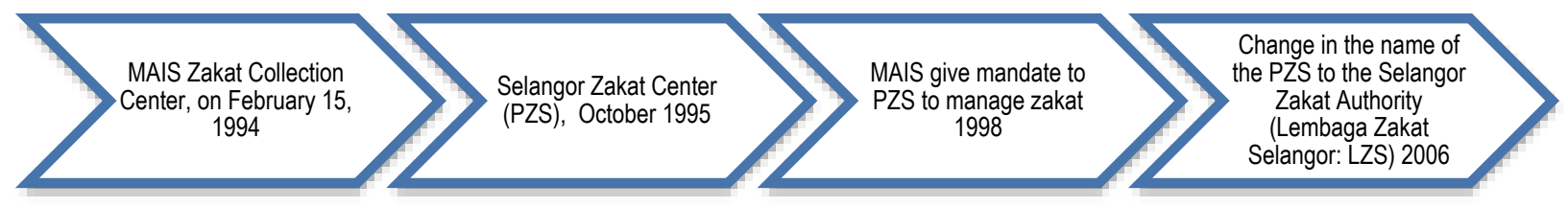

Sources: Ahmad Shahir Makhtar \& Adibah Abdul Wahab (2010)

\subsection{Research Methodology}

The study adopted a qualitative research method consist of an interview and content analysis. Primary data was collected through a semistructured interview session conducted with officers from LZS who are experts in the management of asnaf. The respondent is the Head of the Social Management and Welfare Division of the Asnaf Distribution Operations. Library research was conducted to collect preliminary information about the background of the study. Secondary data sources comprised of research on zakat books, scholarly articles, journals, thesis, conference papers and information of zakat distribution from the official website zakat institution. The interview data and secondary data were subsequently analyzed through content analysis. The limitation on this study will only focus the state of Selangor and into the asnaf of al gharimin.

\subsection{Finding}

Based on Surah At-Taubah verse 60, eight groups of asnaf are eligible to received zakat. LZS have divided the eight asnaf according to two categories which are asnaf muqaddam and asnaf muakkhar. First, asnaf muqaddam is the priority asnaf. Either the collection of zakat increases or decreases, asnaf muqaddam should prioritize his life's necessities. Asnaf muqaddam is categorized as poor, needy, amil and muallaf. Second category is known as asnaf muakkhar. Asnaf muakkhar is asnaf that set later from asnaf muqaddam. Asnaf muakkhar consist of al-gharimin, ar- riqab, fisabilillah and ibnu sabil. Zakat funds will be given priority to asnaf muqaddam first and then to asnaf 
muakhar. In interpreting scriptures about asnaf, Imam Ibn Kathir states that the poor and needy were to be serviced first since they were more entitled than others due to their severe need for assistance.

According to the respondent, the determination of asnaf muqaddam and asnaf muakkhar are based on maqasid Shariah. The meaning of maqasid Shariah is the main purpose and the great secret contained in Islamic Shariah. The Muslim scholars have categorized the whole range of maqasid Shariah in the descending order of importance into three categories: daruriyyat (the essential), hajiyyat (the complementary) and tahsiniyat (the desirable or the embellishments).

\subsection{Practices of asnaf al gharimin according to LZS}

According to section 47 of the Administration of the Religion of Islam (State of Selangor) Enactment 2003 [En. 1/2003], the Fatwa Committee for the State of Selangor define al gharimin according to Shafie'e and Hanbali school are people who owe either debt to themselves or debt to others and whether they are meant to make something good (obey Allah). The conditions for gharimin needing help are as follows:

i. The applicant has no financial assets or resources beyond his basic requirements.

ii. Loans made in halal and permissible (mubah) matters.

iii. $\quad$ There is an urgent need to settle the debt.

iv. $\quad$ There will be harmful to self and family if the debt is not paid.

v. Gharimin, who is indebted to solving basic issues such as health, primary and secondary education, food, temporary shelter and any debt to increase religious dignity, are directly supported by the provision of asnaf gharimin without regard to the amount incurred.

vi. Gharimin, who is indebted to resolve issues other than condition (5) mentioned above, is aided by the provision of asnaf gharimin by qardhul hasan and required to undergo a period of recovery

\subsection{Zakat distribution for asnaf al gharimin}

According to the respondent, the process to distribute zakat for asnaf al gharimin by LZS is through multiple methods. Firstly, is through the identification of amil qariah. Amil qariah is responsible for conducting a census on Muslims in a particular mosque that is eligible for zakat, and fitrah Amil qariah also monitor the welfare of the poor, needy, and muallaf in a particular mosque to ensure the asnaf are not miss out from receiving zakat. Secondly, individuals who encounter debt problems may come directly to the LZS counter and fill out the form for the zakat application. LZS then do the registration and screening process to ensure the person is eligible to consider as asnaf al gharimin. Lastly, since zakat al gharimin in Selangor focuses on medical expenses, LZS has taken the initiative to allocate RM2.5 million per year zakat distribution for selected government and public university hospitals. The zakat fund can be applied to patients who cannot pay the medical expense after being treated there. The applicant may apply for the zakat through the social department of the hospital.

\subsection{Types of zakat aid to asnaf al-gharimin}

Compared to other states, some states include medical debt in the categories of poor and needy. LZS have a focus on medical debt as the main zakat aid for asnaf al gharimin. However, there are few other types of zakat aid given to the zakat recipient in this gharimin category. Al gharimin is not necessary the person who is categorized as asnaf poor and needy. However, the recipient may also be someone who earns up to Rm15,000 monthly but encounters a financial or health problem which if the problem has not been helped by zakat institution, it will lead him to the involvement of debt with others. According to respondent, the discussion on this type of zakat is explained in Table 4.3.

\subsection{Discussion}

LZS have implemented the distribution according to the interpretation by the State Religious Council of Selangor. The zakat distribution is given to individuals who have burdens to bear. Some of the recipients of asnaf gharimin actually already have jobs and income, however due to incidents that cause the individual to be unable to continue daily life to earn income allows the individual to receive zakat in the category of al gharimin. From implementation perspective of the distribution of asnaf gharimin, the distribution was not given arbitrarily but had to go through a strict review by the zakat officer to enable the zakat to reach the right people. The zakat distribution in asnaf al gharimin reach to the optimum level where it show in Table 1.1 with the amount of distribution decreased in 2020 . It shows that reduction of receiver of zakat al gharimin.

\subsection{Conclusion \& Recommendation}

In conclusion, asnaf al gharimin is one of the eight asnaf mentioned in the Quran. LZS has outlined three types of zakat aid to asnaf algharimin, including hemodialysis assistance, medical assistance and living necessities assistance. This allocation of asnaf gharimin is not confined to those in the poor but can also be offered to high-income individuals however having criticial financial problems, will cause indebtedness to others. The practice of al gharimin in LZS is to prevent zakat recipients from getting into debt. This LZS aid helps the 
Muslim community confront unexpected life shocks and avoid debt towards illegitimate sources. This study proposes that future research on gharimin asnaf is expanded by analyzing the effectiveness of gharimin distribution in helping the asnaf life.

Table 4.3: Types of zakat aid to asnaf al-gharimin

\begin{tabular}{|c|c|c|}
\hline $\begin{array}{l}\text { Types of zakat aid to } \\
\text { asnaf al-gharimin }\end{array}$ & & Explanation \\
\hline \multirow[t]{3}{*}{$\begin{array}{l}\text { Life necessities debt } \\
\text { assistance }\end{array}$} & Individual & $\begin{array}{l}\text { Life necessities for individuals include food, medicine, education, housing and transportation. As for } \\
\text { house rental payments, LZS offer assistance in helping the tenant pay their house rental in medium and } \\
\text { low-cost houses only. LZS require evidence such as a letter from the house owner, the owner's } \\
\text { identification card, and the electricity and water bills of the house. Besides that, for transportation, car } \\
\text { financing also will be paid by LZS. All this assistance by LZS is paid on a one-off payment once a year } \\
\text { until the debt settlement. }\end{array}$ \\
\hline & Institution & $\begin{array}{l}\text { Requirements for institutions such as electricity bills, water bills and building rent. LZS will help pay the } \\
\text { outstanding bills. Bill payment for electricity must get the red letter from Tenaga Nasional Berhad, then } \\
\text { officers of LZS will investigate the institution itself. }\end{array}$ \\
\hline & $\begin{array}{l}\text { Management of } \\
\text { the Muslim } \\
\text { corpse without } \\
\text { the heir }\end{array}$ & $\begin{array}{l}\text { The body must be } 4 \text { or } 5 \text { years in the hospital without being claimed by their heirs. The important } \\
\text { requirement for the corpse is Islam, and it does not matter about the resident. LZS will help pay for those } \\
\text { who are managing the corpse. }\end{array}$ \\
\hline $\begin{array}{l}\text { Medical debt } \\
\text { assistance }\end{array}$ & & $\begin{array}{l}\text { LZS have focused on asnaf, who required a fund for medical assistance to be categorized as asnaf al } \\
\text { gharimin. There are several forms of assistance listed in this medical assistance. Firstly, LZS helping in } \\
\text { the form of medications used by patients. LZS have a medical advisory committee consist of professionals } \\
\text { in the medical line. The purpose of this team is to advise the LZS and recommend suitable medication } \\
\text { used by the patient. Therefore, all asnaf in this category will only apply for verified medication } \\
\text { recommended by a medical doctor. The doctor must approve any health supplement if it is needed to be } \\
\text { taken. Secondly, LZS also offer monthly medical assistance for those who need such as milk and } \\
\text { pampers. Thirdly, is surgical financial assistance where the asnaf may go to the social department to } \\
\text { apply for zakat. Lastly is in the form of medical equipment aid /tools, such as wheelchairs, sticks, } \\
\text { prosthetic legs, and hearing aids. }\end{array}$ \\
\hline $\begin{array}{l}\text { Dialysis treatment debt } \\
\text { assistance }\end{array}$ & & $\begin{array}{l}\text { For those undergoing kidney dialysis treatment are entitled to be in the category of asnaf al gharimin. } \\
\text { For example, dialysis treatment for RM150 per treatment and added with an injection of RM70, which } \\
\text { cost RM220 per treatment. The treatment should be done three times a week. Even though the person } \\
\text { has income, if the zakat institution does not help them, they will be in debt due to an increase in the } \\
\text { monthly commitment for dialysis treatment. The hemodialysis treatment is only valid at the } 120 \text { panels of } \\
\text { the hemodialysis centre appointed by LZS. The centre must comply with the government guidelines to } \\
\text { operate the hemodialysis centre and ensure all asnaf have been treated well of the hemodialysis centre } \\
\text { appointed by LZS to ensure the centre follows the government guidelines to operate the hemodialysis } \\
\text { centre and ensure all asnaf have been treated well. }\end{array}$ \\
\hline
\end{tabular}

Source: Interview with respondent

\section{References}

Ahmad Shahir Makhtar \& Adibah Abdul Wahab (2010), Pengurusan Zakat Di Negeri Selangor: Isu dan Cabaran, Prosiding Konvensyen Kebangsaan Perancangan \& Pengurusan Harta dalam Islam 2010, Jabatan Syariah, Fakulti Pengajian Islam UKM, 14 Julai 2010, di Bilik Senat, Bangunan Canselori, UKM

Al-Qaradawi. (2011). Figh al-zakah: A comprehensive study of zakah regulations and philosophy in the light of the Qur'an and sunnah. Kuala Lumpur: Islamic Book Trust

Azman Ab Rahman, Hasanah Abd Khafidz (2015), Ensiklopedia Asnaf dan Skim Agihan Zakat di Malaysia. Univeristi Sains Islam Malaysia, Bandar Baru Nilai. Negeri Sembilan.

Daud, M. N., \& Ismail, H. (2017). Agihan Zakat Terhadap Asnaf Al- Ghārimīn Menurut Pandangan Ulama dan Amalan Masa Kini Pengertian Al- Ghārimīn. Jurnal Perspektif: Special Issue 1, 1(1), 1-12.

Hasan Bahrom. (2011). Asnaf Gharimin dan Ibn Sabil. In Hasan Bahrom, Abd Halim Mohd Noor, \& Rawi Nordin (Eds.), Figh Zakat Malaysia. Pusat Penerbitan Universiti (UPENA), UITM. 2011

Head of the Social Management and Welfare Division of the Asnaf Distribution Operations (2019) Interview with Lembaga Zakat Selangor, Shah Alam, Selangor

Ibn Manzur (t. t.). Lisan al-'Arab. Kaherah: Dar al-Ma'arif.

Ibrahim, M. F., \& Sahrim, M. (2019). Peranan Agihan Zakat sebagai Alat Kewangan Sosial Islam bagi Melangsaikan Hutang Golongan Al-Gharimin di Malaysia. Labuan EJournal of Muamalat and Society (LJMS), 45-53.

Isamail, M. Z., Rosele, M. I., Mohamad, M. T., \& Sulaiman@Mohamad, A. A. (2015). Aplikasi itihad dalam isu zakat: Satu tinjauan. Seminar Zakat Peringkat E-Prosiding Seminar Zakat. 
Ishak, M. F., Mahmoud, A. M. A., Salleh, H. M., Jamaludin, M. N. H., \& Karim, A. H. A. (2021). Understanding The Concept And Characteristics Of Asnaf Zakat Al-Gharimin Through Hadith Nabawi. Jurnal Al-Sirat, 2(19), 121-129.

Islamic Religious (State of Selangor) Administration Enactment 2003, https://www.zakatselangor.com.my/fatwa-zakat-negeri-selangor/ access on February 3, 2020, Mohamad Uda Kassim (2004), Zakat: teori, kutipan dan agihan, Selangor: Utusan Publications.

Lembaga Zakat Selangor (2020) Summary of Zakat Distribution and Zakat Collection LZS for the year ended 31st December 2020, https://www.zakatselangor.com.my/informasi/laporan-aktiviti-zakat/, access on November 09, 2021

Mohammad, M., Engku Muhammad Tajuddin Engku Ali, \& Harun, S. S. M. (2014). Pentakrifan Asnaf Gharimin di Institusi- Institusi Zakat di Malaysia. Elmtiyaz, 111-120.

Mohammad, M., Khairuldin, W. M. K. F. W., Ali, E. M. T. E., Ismail, D., \& Rahman, S. M. A. S. A. (2014). Qard Hasan Melalui Asnaf Al-Gharimin. Media Syariah, XVI(1), 123-142.

Mohd Fariz Abdul Razak, (2019), Interview with Lembaga Zakat Selangor, Shah Alam, Selangor

Mufti of Federal Territory Official Website, https://muftiwp.gov.my/ms/artikel/irsyad-fatwa/irsyad-fatwa-umum/3902-irsyad-al-fatwa-siri-ke-349-hukum-menggunakan-danazakat-untuk-program-motivasi-anak-anak-asnaf-dan-kakitangan-bank, accessed on February 32020

Mujaini (2005). Golongan penerima zakat; Agihan dana zakat secara lebih berkesan. Pusat Perbitan Universiti (UPENA), UiTM Shah Alam

Omar, M., Kamaruddin, N., \& Sungip, F. (2016). Konsep Zakat dan Peranannya Terhadap Masyarakat Sejagat g. Muzakarah Fiqh \& International Fiqh Conference, (November), 68-86

Rosele, M. I., Md Ariffin, M. F., Ramli, M. A., \& Isamai, M. Z. (2016). Pendekatan ljtihad Kontemporari Dalam Isu Semasa di Malaysia. Jurnal Islam Dan Masyarakat Kontemporari, 13(2), 45-57. https://doi.org/10.37231/jimk.2016.13.2.163

Sayed Sabiq (1983) Fikh Sunnah, Bandung: PT al-Maarif

Tahir, R. M., \& Yusof, S. M. (2014). Status Individu Muflis dalam Asnaf Al-Gharimin. International Journal of Business and Technopreneurship, 4(3), 477-494.

Wahid, H. A., Ramli, M. A., Razak, M. I. A., \& Zulkepli, M. I. S. (2017). Determination of Zakat Recipient to Flood Victims. International Journal of Academic Research in Business and Social Sciences, 7(12) 